TECHNICAL SCIENCES AND TECHNOLOGIES

УДК 676.274

DOI: $10.25140 / 2411-5363-2021-2(24)-159-170$

Романія Черьопкіна, Анна Денисенко, Ірина Дейкун, Ірина Трембус

\title{
ПАКУВАЛЬНИЙ ПАПІР ІЗ НАПІВФАБРИКАТІВ ОБГОРТОК КАЧАНІВ КУКУРУДЗИ
}

Вивчено можливість використання напівфабрикатів, отриманих із обгорток качанів кукурудзи для виготовлення пакувальних видів паперу. Показано залежність фібрилювання волокон із обгорток від ступеня їх делігніфікаиії. Проаналізовано фракиійний склад маси після розмелювання. Показано, що натронно-содові напівфабрикати із обгорток за невисоких витрат реагентів 10 та $14 \%$ в од. $\mathrm{Na}_{2} \mathrm{O}$ та нетривалого часу обробки 15 mа 30 хв $i$ температури $100{ }^{\circ} \mathrm{C} \mathrm{ma} 160{ }^{\circ} \mathrm{C}$ характеризуються високими паперотворними властивостями. Зважаючи на доступність обгорток кукурудзи, легкість їх делігніфікаиії та високі показники міцуності, вони можуть успішно використовуватися як целюлозовмісної сировини для виготовлення паперу обгорткового, для пакування текстильних матеріалів, для обкладинок зошитів.

Ключові слова: обгортки; напівфабрикати; фібрилювання; папір обгортковий; для пакування, обкладинок зошитів.

Рис.: 7. Табл.: 2. Бібл.: 20.

Актуальність теми дослідження. Одним із найбільш конкурентних секторів світової економіки, що розвивається динамічно і стабільно, є пакувальна індустрія. Цьому сприяє передусім роздрібна торгівля, а саме розвиток інтернет-торгівлі, що є мотиватором зростання попиту на таропакувальні матеріали.

3 огляду на потреби сьогодення, паперова упаковка повинна бути екологічною, безпечною для навколишнього середовища і задовольняти нові потреби споживача. Упаковка в корнавірусний період відіграє виняткове значення як захисний, стерильний i бар'єрний матеріал, що в майбутньому збереже своє домінуюче значення.

Постановка проблеми. За даними компанії IndexBox, уже 2018 році об'єми споживання пакувального паперу у світі становили 22,9 млрд дол. США, що на 7,2 \% більше, ніж у попередньому році [1].

У 2020 та 2021 роках пандемія коронавірусу ще сильніше каталізувала тенденції розвитку целюлозно-паперової промисловості в сторону випуску паперу та картону для упаковки. Це чітко прослідковується на перепрофільованих підприємствах із випуску паперу для письма та друку [2]. Прикладом також є австрійська фабрика Brusk, де замість газетного паперу планується випуск макулатурного картону [3].

Нині основною сировиною для підприємств, що виробляють пакувальні види паперу та картону є макулатура. Необхідно зауважити, що в ході перероблення макулатури середня довжина волокна і здатність до утворення міжволоконних зв'язків поступово зменшується. Таким чином, якість готового продукту буде знижуватися. Крім того, деякі види паперу й картону із самого початку не придатні до повторного перероблення. Для покращення паперотворних властивостей вторинних волокон є закономірна необхідність отримання і додавання у масу первинного волокна [4]. Зважаючи на загальносвітові тенденції щодо обмеження використання деревини як сировини з метою захисту навколишнього середовища, це змушує промисловість знаходити альтернативні недеревні джерела [5; 6].

Аналіз останніх досліджень і публікацій. Впродовж останніх десяти років загалом спостерігається тенденція до спаду споживання паперової продукції [7]. Завдяки потужному розвитку цифрових технологій потреби в целюлозі й папері постійно знижуються. Це пояснюється зменшенням використання різних видів поліграфічного паперу, особливо газетного, оскільки основними носіями інформації стають електронні видання і вони замінюють друковану продукцію, книги, газети журнали [7]. Період пандемії відзначився суттєвим впливом також на зниження споживання офсетного, писального паперу через онлайн роботи офісів, навчання студентів та школярів. Водночас відзначається стійке зростання паперової та картонної упаковки [2; 7]. Така тенденція притаманна вітчизняним підприємствам, але поглиблена ще проблемами низької якості вторсировини та ії̈ наявно-

(C) Черьопкіна Р. I., Денисенко А. М., Дейкун I. М., Трембус I. В., 2021 
сті. Як відзначає голова асоціації «УкрПапір», традиційно з року в рік спостерігається дефіцит вторинних ресурсів [8]. За оцінками спеціалістів, потреба в макулатурі сягає до одного мільйона тонн, з яких приблизно п’яту частину приходиться імпортувати [8; 9].

Спостерігається, що основною причиною такого стану є низький рівень збору вторинної сировини, іiі сортування та регенерації. В умовах пандемії різко скоротилася заготівля макулатури як в Україні, так і в Свропі, що призвело до їі нестачі та подорожчання [8; 9]. Одним зі шляхів вирішення сировинної бази для виробництва паперу може бути перероблення недеревних однорічних рослин у вигляді обгорток качанів кукурудзи, ріпаку, сої з отриманням первинного волокна. Раніше в багатьох роботах було науково обгрунтовано доцільність їхнього використання для отримання якісних волокнистих напівфабрикатів [5; 6; 10-14].

Мета дослідження статті полягає в ефективному застосуванні волокнистих напівфабрикатів, отриманих екологічно чистим натронно-содовим способом із обгорток качанів кукурудзи для виготовлення пакувальних видів паперу.

Виклад основного матеріалу. На вихід і фізико-механічні показники напівфабрикатів впливає хімічний склад та морфологічна будова сировини.

Відомо, що волокнисті напівфабрикати, отримані з недеревних видів, відрізняються від деревних напівфабрикатів різноманіттям анатомічних елементів. До них відносять прозенхимні (луб'яні волокна) та паренхимні клітини, судини, клітини епідермісу. Паперотворні властивості таких напівфабрикатів будуть залежати від співвідношення анатомічних елементів, а також від способу варіння та ступеня їх проварювання [15].

У роботі проведено мікроскопічне дослідження волокнистих напівфабрикатів (ВНФ), отриманих натронно-содовим способом у ході варіння за температури $160{ }^{\circ} \mathrm{C}$ з витратами активного лугу $14 \%$ в од. $\mathrm{Na}_{2} \mathrm{O}$ від маси абс. сух. сировини з просочуванням 15 хв і тривалістю варіння за кінцевої температури 30 хв.

У ході проведення мікроскопічного дослідження отриманих ВНФ використано розчин хлор-цинк-йод (реактив Херцберга) для забарвлення волокон, який готували згідно стандарту [15]. На волокна, які знаходяться на предметному склі, наносили 2-3 краплі розчин хлор-цинк-йоду, ретельно перемішували і накривали покрівельним склом. Надлишок розчину видаляли фільтрувальним папером. Після висушування зразок поміщали на столик мікроскопа і робили фото. Отримані результати наведено на рис. 1.
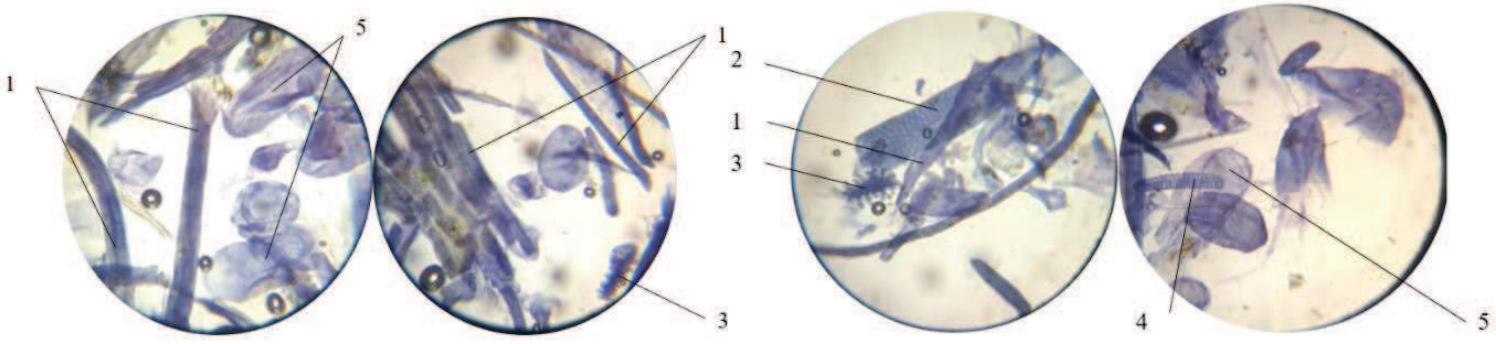

Рис. 1. Фото досліджень зразків ВНФ під мікроскопом:

1 - луб'яне волокно товстостінне та тонкостінне; 2 - членик пориста судина;

3 - клітини епідермісу; 4 - променева паренхимна клітина;

5 - бочковидна паренхимна клітина

На рис. 1 видно луб'яні довгі волокна, наявні товстостінні та частково тонкостінні, які мають трохи здерев'янілі стінки, тонкий канал, поперечні зрушення і повздовжню шорсткість, кінці волокна заокруглені й часто роздвоєні вилоподібно, а після розмелювання кінці мають вигляд кісточки. Як видно із рис. 1, луб'яні волокна добре делігніфіковані. Технічний напівфабрикат містить значну кількість паренхимних клітин, переважно судин у вигляді тонкостінних клітин з округлими краями, переважно еліптичної, 
бочкоподібної та видовженої форми, які у 2-10 разів ширші за волокна [15]. За даних умов варіння судини зберіглися. Для однорічних характерно наявність спіральних судин 3 овальними або круглими порами, які розташовуються на всій поверхні [11-15]. Епітеліальні клітини або клітини епідермісу видно у формі двосторонніх пилочок зі слабовираженою пильчатістю. Вони відрізняються за формою та розміром. Клітини епідермісу, в основному, втрачаються під час варіння, але у даному випадку вони добре делігніфіковані та збереглися у масі, що разом із судинами підвищує вихід напівфабрикату. Зважаючи на наявність у масі значної кількості судин та паренхимних клітин, можна передбачити високі сорбційні властивості матеріалу [6;15].

Для характеристики волокон досліджували фракційний склад отриманих волокнистих напівфабрикатів із використанням приладу Каяні. Визначення довжини волокна проводили для маси, отриманої у процесі варіння січки обгорток натронно-содовим способом, за кінцевої температури варіння $160{ }^{\circ} \mathrm{C}$ тривалістю 15 хв, за витрат активного лугу $14 \%$ в од. $\mathrm{Na}_{2} \mathrm{O}$ від маси абс. сух. сировини, у випадку без процесу просочення для паперу та з просоченням для напівфабрикатів. Дані, отриманні у процесі досліджень для довжини волокна, наведено на рис. 2.

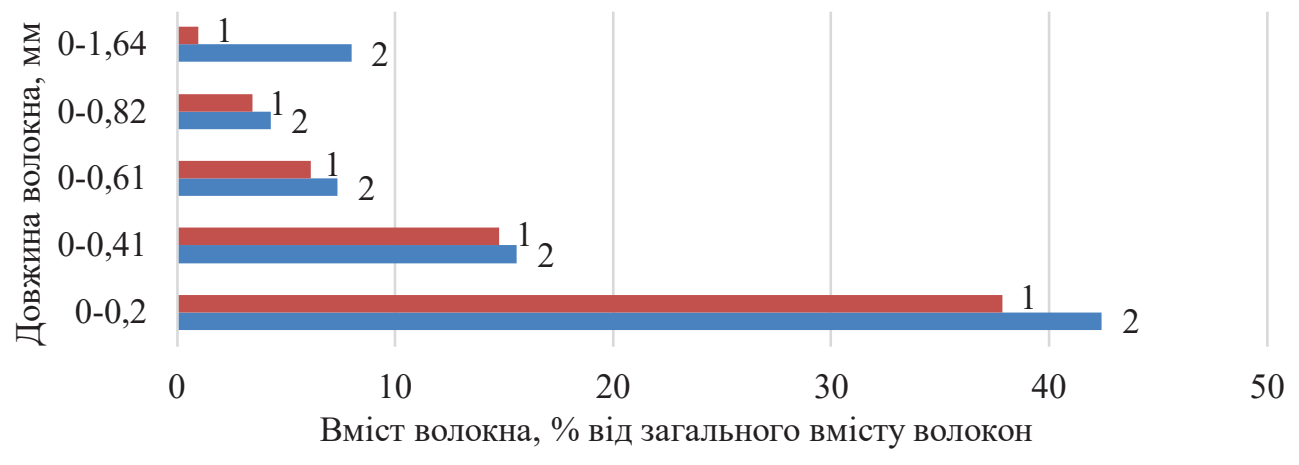

Рис. 2. Фракційний склад зразків напівфабрикатів із обгорток, отриманих за температури $160{ }^{\circ} \mathrm{C}$, тривалістю 15 хв, за витрат активного лугу $14 \%$ в од. $\mathrm{Na}_{2} \mathrm{O}$ : 1 - з просочуванням (ВНФ); 2 - без просочування (папір)

Із діаграми (рис. 2) розподілу волокон за довжиною можна побачити, що волокна в масі розподілені за довжиною таким чином: більшу частину(близько 38 \%), у ВНФ займають волокна завдовжки 0,20 мм. Зі збільшенням довжини волокна їх кількість зменшується, наприклад: волокна довжиною $0,41,0,61,0,82$ мм - вже становлять близько 15,$6 ; 7,4$ та 4,3 \% відповідно. Однак треба зауважити наявність у масі достатньо довгих волокон довжиною 1,02-1,23 мм - 2-1 \% і навіть близько 0,15\% від загального вмісту волокон таких, що мають довжину вище за 1,44 мм. Для порівняння, у папері зі ступенем млива $55^{\circ}$ ШР на $4 \%$ більше волокон довжиною 0,20 мм. Зі збільшенням довжини волокна їх кількість закономірно зменшується.

Аналізуючи отримані дані можна зробити висновок, що зразки мають полідисперсне розподілення волокон, особливо в області коротких. У ході розмелювання напівфабрикатів утворюється значна частина дрібних волокон за рахунок превалювання процесу укорочення волокон над фібрилюванням. Дана закономірність пояснюється особливостями залягання фібрил, під достатньо гострим кутом у стінці клітин обгорток, що суттєво утруднює процес розділення на окремі фібрили.

Для фракційного складу зразків ВНФ та паперу характерна однакова закономірність у розподілі. Такі розміри і фракційний склад волокон є характерними для недеревних видів рослинної сировини, тому постає питання ефективності самостійного використання напівфабрикатів із обгорток для виробництва паперу та в композиції з іншими напівфабрикатами $[6 ; 15]$. 
Наступним етапом роботи було виготовлення пакувальних видів паперу на основі напівфабрикатів, отриманих натронно-содовим способом із обгорток кукурудзи.

Виготовлення обгорткового паперу. Маючи досвід розмелювання напівфабрикатів 3 метою визначення показників їхньої міцності, цей процес вели таким чином, щоб не допустити суттєвого укорочування волокон [5]. Тому для отримання лабораторних відливок паперу використовували вологі ВНФ, які отримували після делігніфікації. Тобто волокна були добре набряклими у воді, м'якими, пластичними, що покращувало внутрішнє фібрилювання, а відповідно, відбулося збільшення питомої поверхні волокна. Відомо, що під час набрякання волокон когезійні сили всередині волокон послаблюються, розрихлення фібрил полегшується і збільшується гнучкість самих волокон. Під час механічної дії на волокна відбувається індивідуальне розрихлення фібрил. Одночасно на поверхні фібрил утворюється наліт із целюлозних молекул, дрібних кристалітів, фібрилок, за рахунок яких збільшується загальна поверхня, вивільняється велика кількість активних гідроксильних груп для утворення міжволоконних зв'язків. Розмелювання кожного напівфабрикату вели окремо у ВРА.

Однак потрібно зауважити, як це було встановлено раніше, що волокна обгорток здатні до укорочення через косе розташування фібрил у стінці клітин [5; 11-15]. ВНФ із обгорток, отримані за температури $100{ }^{\circ} \mathrm{C}$ з витратами акт. лугу 10 та 14 \% в од. $\mathrm{Na}_{2} \mathrm{O}$ від маси абс. сух. сировини нерівномірно фібрилювалися - поряд із добре розробленими волокнами в масі містилися майже не фібрильовані і деяка кількість дріб'язку. Середній ступінь млива становив біля 45-50 ШР. Зовнішній вигляд зразків показано на рис. 3.

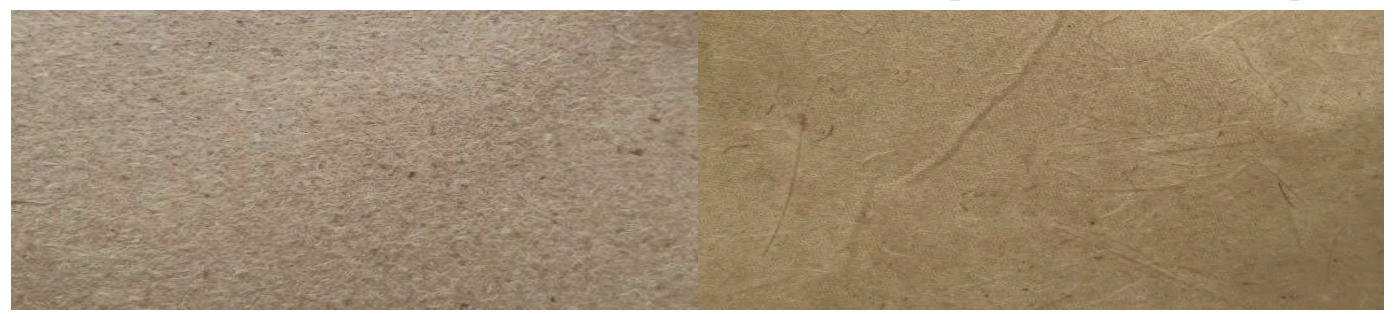

Рис. 3. Зовнішній вигляд зразків волокнистих напівфабрикатів із обгорток качанів кукурудзи

У результаті варіння обгорток за вищої температури $160{ }^{\circ} \mathrm{C} з$ витратами активного лугу 10 та $14 \%$ в од. $\mathrm{Na}_{2} \mathrm{O}$ отримано волокнисті напівфабрикати добре делігніфіковані, тому під час розмелювання маса була більш однорідною та добре фібрильованою. Виготовлення відливок на ЛА-1 відбувалося без скручування листа в процесі сушіння, і вони легко знімалися.

На листовідливному апараті відливали по три зразки строго необхідної маси, сушили, зважували. Після кондиціювання їх піддавали випробуванням для визначення показників міцності. Отримані відливки з невибіленої маси мали своєрідний пергаментний вигляд. Колір зразків від світло жовтого до темно жовтого забарвлення з приємним, ледь відчутним запахом кукурудзи.

Обгорткові види паперу рекомендується виготовляти з використанням різних волокнистих напівфабрикатів, які будуть мати відповідне застосування залежно від показників міцності. Для більшості марок паперу $\left(\mathrm{B}, \mathrm{O}_{1}, \mathrm{O}_{2}\right.$, Д, $\mathrm{E}$, Ж) основними показниками $\epsilon$ розривна довжина та ступінь проклеювання [16]. Показники міцності отриманих зразків наведено на рис. 4.

Як видно із діаграми, використання напівфабрикатів, отриманих за температури $100{ }^{\circ} \mathrm{C}$ з витратами активного лугу $10 \%$ в од. $\mathrm{Na}_{2} \mathrm{O} \epsilon$ мало придатним для виготовлення обгорткового паперу із-за низьких значень розривної довжини. Для підвищення даного показника необхідно досягти глибшої делігніфікації сировини, що дозволить підвищити 
гнучкість окремих волокон, а отже, і покращити їхню здатність до фібрилювання в ході розмелювання. Тому за такої самої температури і підвищених витрат активного лугу до $14 \%$ та збільшеної тривалості варіння відповідно 30 та 45 хв отримані зразки паперу досягають показників розривної довжини, які відповідають нормам стандарту для марок

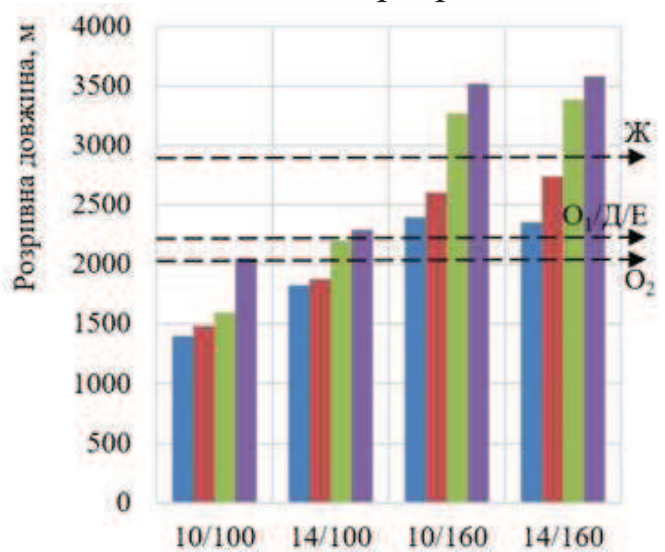

Витрати активного лугу, $\%$ від маси абс. сух. сировини / Температура варіння, ${ }^{\circ} \mathrm{C}$

- без просочування, варіння 15 хв; - без просочування, варіння 30 хв; - $з$ просочування.и 15 хв, варіння $15 x_{6}$; - $з$ просочування. 15 хв, варіння 30 хе

Рис. 4 - Показник розривної довжини обгорткового паперу

$\mathrm{O}_{2}, \mathrm{O}_{1}$, Д та Е. Кращі показники розривної довжини досягнуто у випадку використання ВНФ, отриманих за температури $160{ }^{\circ} \mathrm{C}$ з витратами активного лугу 10 та $14 \%$ в од. $\mathrm{Na}_{2} \mathrm{O}$ і як видно із діаграми, їхні значення досить близькі між собою. Це пояснюється тим, що напівфабрикати 3 меншим вмістом залишкового лігніну більш еластичні за рахунок кращого набухання, легше піддаються фібрилюванню з утворенням меншої кількості дріб'язку. Взаємне розташування довгих і коротких волокон під час формування листа покращує однорідність структури і його просвіт, підвищує щільність і зімкнутість, що позитивно відображається на його міцності. Відповідно до отриманих закономірностей, розривна довжина листа обгорткового паперу залежить від внутрішнього фібрилювання волокна та кількості дрібної фракції, яка утворюється в ході розмелювання.

Показник опору продавлюванню для обгорткового паперу масою 80 г/м² залежно від якості напівфабрикату знаходиться в межах 55-185 кПа.

Відомо, що цей вид паперу може виготовлятися проклеєним і без проклеювання. Характерною особливістю використання напівфабрикатів, отриманих із недеревних видів для виготовлення паперу, $є$ їх високий ступінь самопроклеювання. Це забезпечується наявністю в масі значної кількості геміцелюлоз за одночасної зольності, що не вимивається, та адсорбційної здатності волокон [6]. Визначення ступеня проклеювання обгорткового паперу проводили штриховим методом [17].

Суть цього методу полягає в тому, що зразок паперу клали на скло під рамку приладу рейсфедера. Рейсфедер заповнювали чорнилом і плавно опускали на зразок паперу. Потім горизонтальним рухом каретки по рамці проводили штрихи під кутом $45^{\circ}$ і залишали для висихання на 2 год. За результат приймали максимальну ширину чорнильного штриха, без його розпливання та який не переходив на зворотну сторону зразка. У результаті було отримано значення в межах 0,6-1 мм, що цілком задовольняє вимоги до цього виду паперу без додаткових технологічних дій.

Папір для пакування текстильних матеріалів і виробів виготовлено масою $1 \mathrm{~m}^{2}$ $(83 \pm 3,5)$ г із напівфабрикатів, отриманих із обгорток качанів кукурудзи за різних режимів варіння: за температури $100{ }^{\circ} \mathrm{C} 14 \%$ в од. $\mathrm{Na}_{2} \mathrm{O}$ та за температури $160{ }^{\circ} \mathrm{C}$ з витратами активного лугу 10 та $14 \%$ в од. $\mathrm{Na}_{2} \mathrm{O} 3$ просочуванням та без просочування січки і варінням за кінцевої температури 15 та 30 хв. У результаті нетривалого варіння отримано напівфабрикати різної якості з яких виготовляли лабораторні зразки паперу.

Для отримання відливок паперу, використовували вологі напівфабрикати, які розмелювали у ВРА до досягнення 50-55 ШР. У виготовлених зразках, після кондиціювання, визначали розривне зусилля, опір продавлюванню та ступінь проклеювання штриховим методом. 


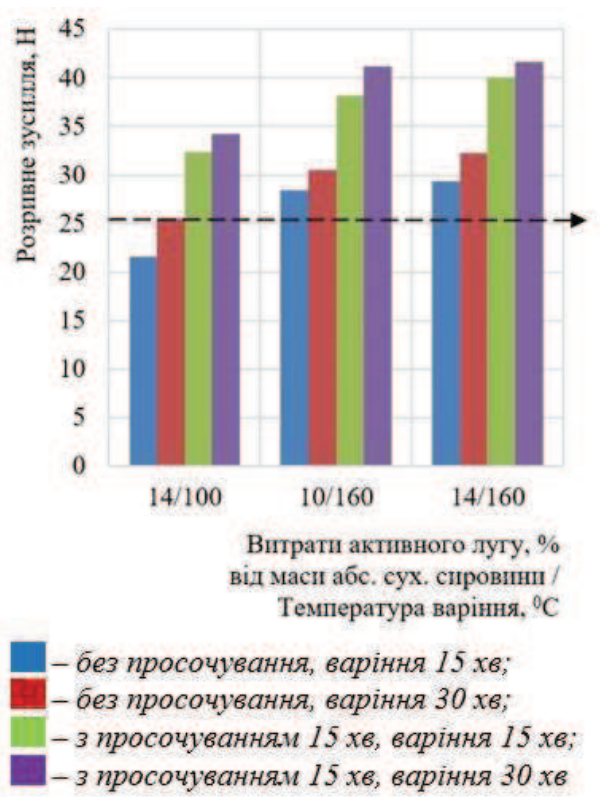

Рис. 5 - Показник розривного зусилля паперу для пакування текстильних матеріалів
Усі зразки виготовлено природного кольору: від світло жовтого до темно жовтого.

Папір характеризується пружними, еластичними тобто деформаційними властивостями до певної міри. Деформаційні властивості проявляються під час дії на матеріал зовнішніх сил, у результаті яких змінюється форма або його об'єм. Після припинення дії сили, зразок відновлює свою початкову форму. Така закономірність найбільше характеризує пакувальні види паперу. Тому механічна властивість паперу для пакування текстильних матеріалів насамперед визначається розривним зусиллям.

Для цього виду паперу рекомендовано розривне зусилля не менше 25,5 Н, яке легко досягається всіма використаними напівфабрикатами, крім отриманих без просочення тривалістю варіння 15 хв (рис. 5.) [18]. Це пояснюється порівняно високим ступенем млива добре делігніфікованої маси, що супроводжується підвищеним фібрилюванням волокон та відповідно утворенням додаткової кількості водневих зв'язків, які надають міцності паперу. Зразки паперу мали однорідну структуру та високу щільність.

Однак для паперу, який було отримано з напівфабрикатів без просочення і варінням лише 15 хв, характерна низька механічна міцність. У ході розмелювання такі волокна частіше піддавалися «рубці», через високий вміст у них лігніну, що надавало їм жорсткості, знижувало їхню пластичність та супроводжувалося наявністю у зразках паперу коротких нерозроблених включень. Їх ефективне використання може бути, у випадку виготовлення, наприклад, картону, де нормується показник жорсткості, або отримані напівфабрикати використовувати для виготовлення паперу у композиції із іншими ВНФ.

Показник опору продавлюванню паперу для пакування текстильних матеріалів знаходиться в межах 80-200 кПа, що повністю задовольняє рекомендовані межі значень [18]. Щодо ступеня проклеювання паперу, то можна стверджувати, що волокнисті напівфабрикати з обгорток найбільш підходять для виготовлення даних видів паперу, без додаткового введення мінеральних наповнювачів, за рахунок самопроклеювання.

Для паперу для обкладинок зошитів механічна міцність у вигляді розривної довжини в середньому за двома напрямками є основним показником. Відомо, що показники міцності в машинному напрямку формування листа завжди переважають над показниками у поперечному напрямку [18]. Це пояснюється направленим розташуванням довгих волокон вздовж руху сітки і рівномірним переплетенням довгих і коротких волокон між собою. У результаті отримується лист без просвітів, однорідний. Однак практичне використання паперу для обкладинок потребує достатньо високих значень розривної довжини в поперечному напрямку також. Це досягається використанням напівфабрикатів, які здатні утворювати міцні міжволоконні зв'язки за невисокого ступеня млива. У композиції паперу використовували напівфабрикати різного ступеня делігніфікації: слабоделігніфіковані за температури $100{ }^{\circ} \mathrm{C}$ та напівфабрикати у вигляді целюлози підвищеного виходу за максимальної температури варіння $160^{\circ} \mathrm{C}$. Всі напівфабрикати розмелювали у ВРА до досягнення $30-55^{\circ}$ ШР. Папір із напівфабрикатів, отриманих за температури $100{ }^{\circ} \mathrm{C}$ містив велику кількість нерозроблених волокон, що негативно впливало на правильне визначення ступеня млива i, відповідно, на показники міцності. Як видно із рис. 6 показників розривної довжини, які задовольняють значення стандарту для 
марки В, було досягнуто у випадку застосування напівфабрикатів, отриманих за максимальної температури варіння $160^{\circ} \mathrm{C}$. Кращі значення отримано для паперу, в композиції якого використовували ВНФ з низьким вмістом лігніну.

Як видно із діаграм 4-6, механічні показники міцності обгорткового паперу, паперу для пакування текстильних матеріалів та для обкладинок зошитів залежать від ступеня делігніфікації напівфабрикатів, які використовували для їх виготовлення. Проте вони всі отримані з рослинних відходів у вигляді обгорток качанів кукурудзи за низьких витрат активного лугу та мінімальної тривалості варіння, що робить привабливими їх застосування у виробництві пакувальних видів паперу з економічного погляду.

Нині відомо багато відходів злакових та бобових культур, які зарекомендували себе як целюлозовмісна сировина з високими паперотворними властивостями $[19 ; 20]$. Тому інтерес викликає поєднання волокнистих напівфабрикатів, отриманих із різних видів недеревної сировини $з$ метою досягнення необхідних споживчих властивостей паперу. А також гнучкість переходу з однієї сировини на іншу без суттєвого впливу на технологічний процес отримання готової продукції.

Тому подальші дослідження проведено з виготовленням різних видів паперу, у композиції яких використовували напівфабрикати, отримані зі стебел ріпаку та сої, які раніше вивчалися та були рекомендовані як джерело целюлозовмісної сировини [20].

Після варіння січки ріпаку та сої натронно-содовим способом за витрат активного лугу $6 \%$ в од. $\mathrm{Na}_{2} \mathrm{O}$ та температури $160{ }^{\circ} \mathrm{C}$, 3 просочуванням 15 хв та варінням за кінцевої температури 30 хв отримано напівфабрикати за виходом та вмістом залишкового лігніну у вигляді напівцелюлози. Показники якості, отриманих напівфабрикатів зі стебел ріпаку та сої, наведено в табл. 1.

Таблиия 1 - Показники якості напівфабрикатів зі стебел ріпаку та сої

\begin{tabular}{|c|c|c|c|c|c|c|}
\hline Сировина & Вихід, \% & Лігнін, \% & $\begin{array}{c}\text { Розривна } \\
\text { довжина, м }\end{array}$ & $\begin{array}{c}\text { Опір } \\
\text { продавлюванню, } \\
\text { кПа }\end{array}$ & $\begin{array}{c}\text { Опір } \\
\text { роздиранню, } \\
\text { мН }\end{array}$ & $\begin{array}{c}\text { Міцність на злом під } \\
\text { час багаторазових } \\
\text { перегинів, к.П.П. }\end{array}$ \\
\hline Ріпак & 79,4 & 17,8 & 2550 & 185 & 315 & 5 \\
\hline Соя & 83,2 & 19,3 & 1900 & 105 & 250 & 3 \\
\hline
\end{tabular}

Як видно із даних табл. 1, за фізико-механічними показниками напівфабрикати із сої мають дещо нижчі значення за вищого виходу. Такі дані можна пояснити тим, що за однакових умов варіння стебла сої менше делігніфікувалися, частково через більший вмісту лігніну у вихідній сировині. Як результат, волокна важче фібрилюються, більше укорочуються і в переважно є коротшими в порівнянні з ріпаком [20].

Для виготовлення паперу ВНФ, отримані зі стебел ріпаку та сої, розмелювали окремо до досягнення $45^{\circ}$ ШР у ВРА, відливали зразки із 100 \% вмістом відповідних волокон та визначали показник розривного зусилля і розраховували значення розривної довжини. Далі використовували їх у композиції з напівфабрикатами, отриманими з обгорток кукурудзи в різному співвідношенні.

У композиції паперу використовували ВНФ, отримані з обгорток натронно-содовим способом із витратами активного лугу $10 \%$ в од. $\mathrm{Na}_{2} \mathrm{O}$, без просочування та 3 просочуванням 15 і 30 хв та варінням за кінцевої температури $160{ }^{\circ} \mathrm{C}$ впродовж 15 та 30 хв. Ко- 
жен волокнистий матеріал розмелювали окремо до 45-50 ШР у ВРА і виготовляли зразки із $100 \%$ вмістом волокон обгорток відповідної маси для кожного виду паперу та визначали показник розривного зусилля і розраховували значення розривної довжини.

Композицію паперу складали строго із відповідними масовими частками кожного виду напівфабрикату (табл. 2). Зразки обгорткового паперу виготовляли масою $1 \mathrm{~m}^{2} 80$ г, паперу для пакування текстильних матеріалів - масою 1 м $^{2} 85$ г та паперу для обкладинок зошитів - масою 1 м² $^{2} 3$ г. Всі види паперу виготовляли натурального кольору волокна.

Таблиия 2 - Показники якості паперу обгорткового, для пакування текстильних матеріалів та обкладинок зошитів, виготовлених у композииї ВНФ, отриманих із обгорток кукурудзи, ріпаку та сої в різних співвідношеннях

\begin{tabular}{|c|c|c|c|c|c|}
\hline \multirow{3}{*}{$\begin{array}{c}\text { Період } \\
\text { підйому } \\
\text { від } 80 \text { до } \\
160 \text { C (хв) }\end{array}$} & \multirow{3}{*}{$\begin{array}{c}\text { Тривалість варіння } \\
\text { за температури } \\
160{ }^{\circ} \mathrm{C}, \text { хв } \\
\text { За витрат ак. лугу } \\
10 \text { \% }\end{array}$} & \multicolumn{4}{|c|}{ Показники міцності паперу } \\
\hline & & \multirow{2}{*}{\begin{tabular}{c|} 
обгорткового \\
Розривна \\
довжина, м \\
\end{tabular}} & \multicolumn{2}{|c|}{$\begin{array}{c}\text { для пакування } \\
\text { текстильних матеріалів }\end{array}$} & \multirow{2}{*}{$\begin{array}{c}\text { для обкладинок } \\
\text { зошитів } \\
\text { Розривна } \\
\text { довжина, м }\end{array}$} \\
\hline & & & $\begin{array}{l}\text { Розривне } \\
\text { зусилля, Н }\end{array}$ & $\begin{array}{c}\text { Опір продавлю- } \\
\text { ванню, кПа } \\
\text { (рекомендовано) }\end{array}$ & \\
\hline \multicolumn{6}{|c|}{ Композиція 100 \% ВНФ із обгорток } \\
\hline 0 & 15 & 2810 & 25,2 & 160 & 2890 \\
\hline 0 & 30 & 3050 & 28,7 & 170 & 3130 \\
\hline 15 & 15 & 3320 & 32,5 & 185 & 3290 \\
\hline 15 & 30 & 3800 & 36,2 & 190 & 3860 \\
\hline \multicolumn{6}{|c|}{ Композиція 100 \% ВНФ із ріпаку } \\
\hline 15 & 30 & 2510 & 26,2 & 155 & 2460 \\
\hline \multicolumn{6}{|c|}{ Композиція 100 \% ВНФ із сої } \\
\hline 15 & 30 & 1840 & 19,4 & 90 & 1910 \\
\hline \multicolumn{6}{|c|}{ Композиція ВНФ із обгорток: ВНФ із ріпаку - 75 : 25} \\
\hline 0 & 15 & 3340 & 31,7 & 185 & 3350 \\
\hline 0 & 30 & 3850 & 33,3 & 189 & 3740 \\
\hline 15 & 15 & 4150 & 39,8 & 196 & 4220 \\
\hline 15 & 30 & 4770 & 42,4 & 205 & 4650 \\
\hline \multicolumn{6}{|c|}{ Композиція ВНФ із обгорток: ВНФ із ріпаку - 50 : 50} \\
\hline 0 & 15 & 3180 & 30,9 & 183 & 3350 \\
\hline 0 & 30 & 3750 & 32,5 & 187 & 3760 \\
\hline 15 & 15 & 3950 & 35,3 & 191 & 3920 \\
\hline 15 & 30 & \begin{tabular}{|l|}
4560 \\
\end{tabular} & 37,8 & 197 & 4480 \\
\hline \multicolumn{6}{|c|}{ Композиція ВНФ із обгорток: ВНФ із сої - 50 : 50} \\
\hline 0 & 15 & \begin{tabular}{|c|}
3050 \\
\end{tabular} & 28,7 & 117 & 3150 \\
\hline 0 & 30 & 3450 & 31,3 & 121 & 3340 \\
\hline 15 & 15 & 3670 & 35,6 & 132 & 3690 \\
\hline 15 & 30 & 4100 & 39,3 & 155 & 4050 \\
\hline ГОСТ & & \begin{tabular}{|c|}
$2000-\mathrm{O}_{2}$ \\
$2200-\mathrm{O}_{1} ;$ Д; Е; \\
$2900-Ж ;$ \\
$3000-\mathrm{B}$
\end{tabular} & 25,5 & 120 & $\begin{array}{c}\text { не менше } 2300 \\
\text { для марки В }\end{array}$ \\
\hline
\end{tabular}

Як видно із даних табл. 2, використання ВНФ із ріпаку в кількості $25 \%$ у композиції із ВНФ з обгорток від загальної частки дозволяє підвищувати показники міцності в порівнянні зі 100 \% зразками паперу із обгорток на 16-21\%. Треба зауважити, що показники покращуються в ряду використання ВНФ із обгорток з підвищеним ступенем проварювання, за рахунок кращих паперотворних властивостей.

У випадку збільшення в композиції паперу частки напівцелюлози із ріпаку до 50 \%, спостерігається підвищення показників лише на 12-17\%. Тобто зі збільшенням частки ріпакових ВНФ у композиції паперу ще на 25 \% показники міцності знижуються приблизно на 4 \% у порівнянні з попередніми. 
TECHNICAL SCIENCES AND TECHNOLOGIES

Щодо лабораторних зразків паперу, у композиції якого використано ВНФ із сої 50 \% та 50 \% ВНФ із обгорток, то в порівнянні з вихідними напівфабрикатами із обгорток значення розривної довжини та розривного зусилля підсилено приблизно на 8-10 \%. Але, якщо порівнювати із таким самим співвідношенням у випадку застосування у композиції паперу ВНФ із ріпаку, то показники міцності у випадку застосування ВНФ із сої нижчі на 4-7 \%.

Таку закономірність частково можна пояснити тим, що напівфабрикати із сої в процесі варіння слабше делігніфікувалися, ніж ріпаку в результаті отримано масу, яка гірше піддавалася фібрилюванню. Через значну кількість лігніну у волокнах сої утворюється оболонка навколо них, що блокує гідроксильні групи і робить їх важкодоступними для просочування водою, що знижує внутрішнє фібрилювання. Це призводить до зниження міжмолекулярних зв'язків, що послаблює міцність листа. Це підтверджується отриманими мікрофотографіями (рис. 7).

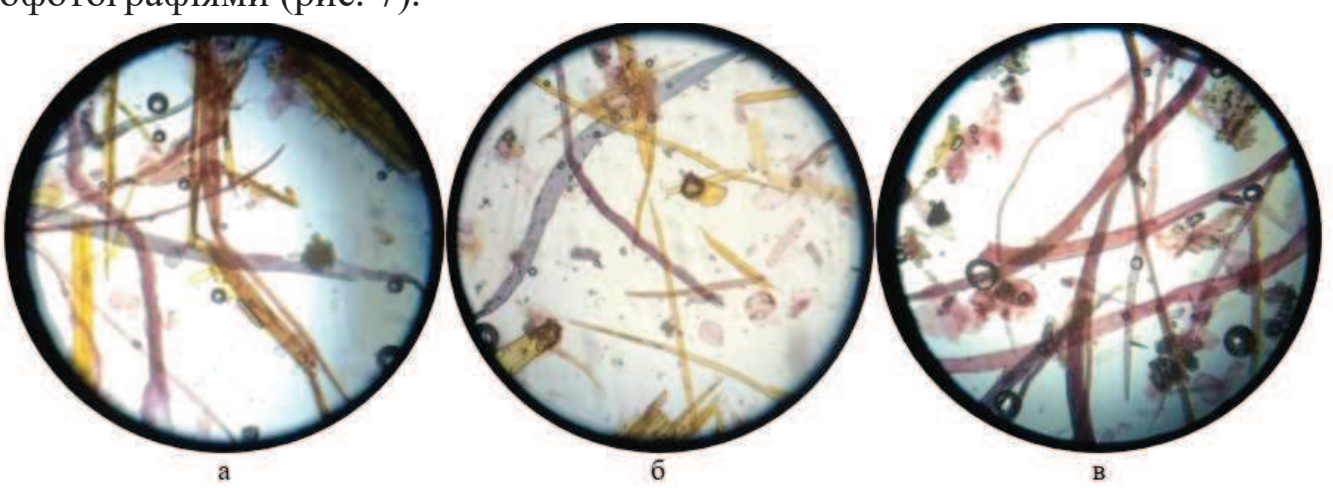

Рис. 7. Зображення волокон паперу під мікроскопом, отриманого з ВНФ обгорток качанів кукурудзи та сої у співвідноченні 50:50 (а); з ВНФ обгорток качанів кукурудзи та ріпаку у співвідношенні 50:50 (б); ВНФ, з обгорток качанів кукурудзи за температури варіння $160^{\circ} \mathrm{C}$

На рис. 7, $а$ видно довгі фіолетово-рожевого кольору різних відтінків волокна обгорток та волокна сої забарвлені у жовті й коричнюваті кольори залежно від концентрації в них лігніну [15].

На рис. 7, б показано композицію паперу із вмістом волокон ріпаку, звідки можна зробити висновок, що вони мають світло жовте забарвлення. Таке забарвлення характерно для напівфабрикатів із нижчим вмістом лігніну, ніж у волокон сої.

Із наведеної ілюстрації рис. 7, в видно, що волокна ВНФ, отриманих з обгорток після варіння довгі, гладкі, добре делігніфіковані, що підтверджується рожевим забарвленням. Поряд видно невеликі вкраплення жовто-коричневих відтінків здерев'янілих клітин епідермісу, характерних для однорічних.

У ході розмелювання слабо делігніфіковані волокна ріпаку та сої піддаються укороченню, що призводить до збільшення кількості дрібної фракції у масі. Однак можна припустити, що вони все ж легше піддаються зовнішньому фібрилюванню, ніж волокна обгорток, які, як відомо, характеризуються розміщенням фібрил у клітинній стінці під кутом до осі, що утруднює їх розроблення навіть в умовах доброї делігніфікації. Під час формування і сушіння зразка з використанням різних напівфабрикатів підвищується щільність упаковки довгих і коротких волокон, що покращує показник розривної довжини.

Висновки. На основі проведених досліджень показано, що напівфабрикати із обгорток качанів кукурудзи, отримані натронно-содовим способом, можуть бути самостійною сировиною для виготовлення пакувальних видів паперу. Показано легкість делігніфікації обгорток у порівнянні зі стеблами ріпаку та сої. Вивчено ефективність використання напівфабрикатів із обгорток у композиції з іншими недеревними волокнами у технології виготовлення обгорткового паперу, паперу для пакування промислових товарів та для обкладинок зошитів. 


\section{Список використаних джерел}

1. Сергеева А. Мировой рынок оберточной бумаги. Потребление растет уверенными темпами. PWPaper GLOBAL, 16 августа 2019. URL: https://sbo-paper.ru/news/archive_world/43045.

2. Кириченко E. Stora Enso намерена закрыть два ЦБК - Kvarnsveden и Veitsiluoto. PWPaper GLOBAL, 21 апреля 2021. https://sbo-paper.ru/news/archive_world/44148.

3. Кириченко Е. Макулатурный тарный картон вместо газетной бумаги. PWPaper GLOBAL, 28 апреля 2021. https://sbo-paper.ru/news/archive_world/44160.

4. Дулькин Д. А., Спиридонов В. А., Комаров В. И. Современное состояние и перспективы использования вторичного волокна из макулатуры в мировой и отечественной индустрии бумаги. Архангельск : Изд-во АГТУ, 2007. 1118 с.

5. Черьопкіна Р. І., Денисенко А. М. Хімічне перероблення обгорток качанів кукурудзи на волокнисті напівфабрикати. Вісник Національного технічного університету Украйни «Київський політехнічний інститут імені Ігоря Сікорського». Серія «Хімічна інженерія, екологія та ресурсозбереження». 2021. № 1(20). С. 63-73.

6. Материалы из нетрадиционных видов волокон: технологии получения, свойства, перспективы применения : монография / под ред. А. В. Вураско. Екатеринбург, 2020. 252 с.

7. Интернет против целлюлозно-бумажной промышленности: последняя статистика из Европы. Открытый лес ПРО. URL: https://wood.openforest.org.ua/9704.

8. Масалов Д. Цена на макулатуру растет. На очереди гофроупаковка. Гофроиндустрия. URL: https:/gofromagazine.com/czena-na-makulaturu-rastet-na-ocheredi-gofroupakovka.html.

9. Індекс будівельної продукції січень-квітень 2021 / Державна служба статистики України. URL: http://www.ukrstat.gov.ua.

10. Cheșcă A.M., Tofănică B.M., Puiţel A.C., Nicu R., Gavrilescu D. Environmentally Friendly Cellulosic Fibers from Corn Stalk. Environmental Engineering and Management Journal. 2018. Vol. 7 (17). Pp. 1765-1771.

11. Nishant D. Kambli, Kartick K. Samanta, Basak S., Chattopadhyay S.K, Patil P. G., Deshmukh R.R. Characterization of the Corn Husk Fibre and Improvement In Its Thermal Stability by Banana Pseudostem Sap. Cellulose. 2018. Vol. 25(9). Pp. 5241-5257.

12. Nishant Kambli, Shantanu Basak, Kartick K. Samanta, Rajendra R. Deshmukh. Extraction of Natural Cellulosic Fibers from Cornhusk and Its Physico-Chemical Properties. Fibers and Polymers. 2016. Vol. 17(5). Pp. 687-694.

13. Nishant D. Kambli, Mageshwaran V., Prashant G. Patil, Sujata Saxena, Deshmukh R.R. Synthesis and Characterization of Microcrystalline Cellulose Powder from Corn Husk Fibres Using BioChemical Route. Cellulose. 2017. Vol. 24(12). Pp. 5355-5369.

14. Narendra Reddy, Yiqi Yang. Biofibers from Agricultural Byproducts for Industrial Applications. TRENDS in Biotechnology. 2005. Vol. 23(1). Pp. 22-27.

15. Зотова-Степановская Н. П. Диагностические признаки недревесных растительных и химических волокон / под ред. Н. П. Зотовой-Спановской. Москва : Лесная промышленность, 1981. 120 с.

16. ГОСТ 8273-75. Бумага обёрточная. Технические условия. Москва : ИПК Издательство стандартов, 1975.

17. ГОСТ 8049-62. Бумага. Штриховой метод определения степени проклейки. Москва : ИПК Издательство стандартов, 1962.

18. Бумага для упаковывания текстильных материалов и изделий. Технические условия (11600-75). Москва : ИПК Издательство стандартов, 1975.

19. Бумага обложечная тетрадная. Технические условия (12056-76). Москва : ИПК Издательство стандартов, 1976.

20. Черьопкіна Р. І., Паньковець С. М. Використання натронно-содових напівфабрикатів із ріпаку в композиції картону. Технологический аудит и резервы производства, (2015). № 6/7(26). С. 25-29.

\section{References}

1. Sergeeva, A. (August 16, 2019). Mirovoi rynok obertochnoi bumagi. Potreblenie rastet uverennymi tempami [World market of wrapping paper. Consumption is growing at a steady pace]. PWPaper GLOBAL. https://sbo-paper.ru/news/archive_world/43045.

2. Kirichenko, E. (April 21, 2021). Stora Enso namerena zakryt dva TcBK - Kvarnsveden $i$ Veitsiluoto [Stora Enso intends to close two pulp and paper mills - Kvarnsveden and Veitsiluoto]. PWPaper GLOBAL. https://sbo-paper.ru/news/archive_world/44148. 
3. Kirichenko, E. (April 28, 2021). Makulaturnyi tarnyi karton vmesto gazetnoi bumagi [Waste packaging instead of newsprint]. PWPaper GLOBAL. https://sbo-paper.ru/news/archive_world/44160.

4. Dulkin, D.A., Spiridonov, V.A., \& Komarov, V.I. (2007). Sovremennoe sostoianie i perspektivy ispolzovaniia volokna iz makulatury $v$ mirovoi i otechestvennoi industrii bumagi [The current state and prospects for the use of secondary fiber from waste paper in the global and domestic paper industry]. Izd-vo, Arkhang. gos. un-ta.

5. Cheropkina, R.I., \& Denysenko, A.M. (2021). Khimichne pereroblennia obhortok kachaniv kukurudzy na voloknysti napivfabrykaty [Chemical processing of corn cob wrappers into fibrous semifinished products]. Visnyk Natsionalnoho tekhnichnoho universytetu Ukrainy «Kyivskyi politekhnichnyi instytut imeni Ihoria Sikorskoho». Seriia «Khimichna inzheneriia, ekolohiia ta resursozberezhennia»Bulletin of the National Technical University of Ukraine "Kyiv Polytechnic Institute named after Igor Sikorsky". Series "Chemical Engineering, Ecology and Resource Conservation", 1(20), 63-73.

6. Vurasko, A.V. (Ed.). (2020). Materialy iz netraditcionnykh vidov volokon: tekhnologii polucheniia, svoistva, perspektivy primeneniia [Materials from non-traditional types of fibers: production technologies, properties, application prospects]. UGLTU.

7. Otkrytyi les PRO. (n.d.). Internet protiv tcelliulozno-bumazhnoi promyshlennosti: posledniaia statistika iz Evropy [Internet against the pulp and paper industry: the latest statistics from Europe]. Retrieved September 4, 2020 from https://wood.openforest.org.ua/9704.

8. Dmitrii Masalov. (2021). Tsena na makulaturu rastet. Na ocheredi gofroupakovka [The price of waste paper is growing. The next step is corrugated packaging]. Corrugated industry. https://gofromagazine.com/czena-na-makulaturu-rastet-na-ocheredi-gofroupakovka.html.

9. Derzhavna sluzhba statystyky Ukrainy [State Statistics Service of Ukraine]. (n.d.). Indeks budivelnoi produktsii sichen-kviten 2021 [Index of construction products January -April 2021]. Retrieved June 2, 2020 from http://www.ukrstat.gov.ua.

10. Cheșcă, A.M., Tofănică, B.M., Puiţel, A.C., Nicu, R., \& Gavrilescu, D. (2018). Environmentally Friendly Cellulosic Fibers from Corn Stalk. Environmental Engineering and Management Journal, 7(17), 1765-1771.

11. Nishant D. Kambli, Kartick K. Samanta, Basak, S., Chattopadhyay, S.K, Patil, P. G., \& Deshmukh, R.R. (2018). Characterization of the Corn Husk Fibre and Improvement In Its Thermal Stability by Banana Pseudostem Sap. Cellulose, 25(9), 5241-5257.

12. Nishant Kambli, Shantanu Basak, Kartick K. Samanta, \& Rajendra R. Deshmukh. (2016). Extraction of Natural Cellulosic Fibers from Cornhusk and Its Physico-Chemical Properties. Fibers and Polymers, 17(5), 687-694.

13. Nishant D. Kambli, Mageshwaran, V., Prashant G. Patil, Sujata Saxena, \& Deshmukh, R.R. (2017). Synthesis and Characterization of Microcrystalline Cellulose Powder from Corn Husk Fibres Using Bio-Chemical Route. Cellulose, 24(12), 5355-5369.

14. Narendra Reddy, \& Yiqi Yang. (2005). Biofibers from Agricultural Byproducts for Industrial Applications. TRENDS in Biotechnology, 23(1), 22-27.

15. Zotova-Stepanovskaia, N.P. (1981). Diagnosticheskie priznaki nedrevesnykh rastitelnykh $i$ khimicheskikh volokon [Diagnostic signs of non-wood plant and chemical fibers]. Lesnaia promyshlennost.

16. Ministerstvo lesnoi promyshlennosti SSSR [Ministry of the timber industry of the USSR]. (1975). Bumaga obertochnaia. Tekhnicheskie usloviia [Wrapping paper. Technical conditions] (GOST 8273-75). IPK Izdatelstvo standartov.

17. Ministerstvo lesnoi promyshlennosti SSSR [Ministry of the timber industry of the USSR]. (1962). Bumaga. Shtrikhovoi metod opredeleniia stepeni prokleiki [Paper. Dotted method for determining the degree of gluing] (GOST 8049-62). IPK Izdatelstvo standartov.

18. Ministerstvo lesnoi promyshlennosti SSSR [Ministry of the timber industry of the USSR]. (1975). Bumaga dlia upakovyvaniia tekstilnykh materialov i izdelii. Tekhnicheskie usloviia [Paper for packing textile materials and products. Specifications] (11600-75). IPK Izdatelstvo standartov.

19. Ministerstvo lesnoi promyshlennosti SSSR [Ministry of the timber industry of the USSR]. (1976). Bumaga oblozhechnaia tetradnaia. Tekhnicheskie usloviia [Cover notebook paper. Specifications] (12056-76). IPK Izdatelstvo standartov.

20. Cheropkina, R.I., \& Pankovets, S.M. (2015). Vykorystannia natronno-sodovykh napivfabrykativ iz ripaku v kompozytsii kartonu [The use of soda and soda semi-finished products from rapeseed in a cardboard composition]. Tekhnolohycheskyi audyt y rezervbl proyzvodstva - Technological audit and production reserves, 6/7(26), 25-29. 
UDC 676.274

\section{Romaniia Cheropkina, Anna Denysenko, Irina Deykun, Irina Trembus}

\section{PACKING PAPER FROM SEMI-FINISHED PRODUCTS OF CORN COBS}

During the pandemic, the pulp and paper industry is in some uncertainty. First of all, it is due to the sharp decline in demand for offset, newsprint and, stationery due to the transition to work, online learning. On the other hand, there is an increase in the use of paper packaging due to the active growth of electronic sales and delivery services for goods and food.

It is traditionally believed that packaging paper is made from secondary resources. It is necessary to note the factors of organization and efficiency of the waste paper collection system, which, at this stage, are not sufficiently regulated, which reduces the possibility of procurement of these raw materials. Also, these materials have limited possibilities of using: losing their paper-forming properties, the complexity of morphological and chemical properties of the mass, which are difficult to control. Therefore, an adequate alternative to fibers may be the production and use of semi-finished products from non-wood species, in the form of rapeseed, soybeans, corn waste for the manufacture of packaging paper.

Ecologically clean natron-soda method from the wrappers of corn cobs at the consumption of active alkali 10 and $14 \%$ in units. Na2O, with pre-impregnation of the chaff for 15 min and without impregnation and cooking for 15 and 30 min at $100^{\circ} \mathrm{C}$ and $160^{\circ} \mathrm{C}$, obtained semi-finished products, which were used for the manufacture of wrapping paper, for packaging textiles, notebook covers. The study shows the quality of grinding of semi-finished products from corn cob wrappers from the degree of delignification. The characteristics of the fractional composition of the mass are given. The polydispersity of the fiber distribution is shown, especially in the short range. This pattern is explained by the peculiarity of the occurrence of fibrils, at an acute angle, in the cell walls, which partially complicates the fibrillation process. A feature of obtaining paper from such raw materials can be considered a high degree of self-sizing. It is ensured by presenting the mass of a significant amount of hemicelluloses with simultaneous non-leaching ash and adsorption capacity of the fibers.

From the semi-finished products obtained at high reagent consumption and temperature of $160^{\circ} \mathrm{C}$, the strength of wrapping paper grades $B, O_{1}, O_{2}$, Д, E, Ж, for packaging textiles and paper for notebook covers of grades $A$, 5 , $B$ is easily achieved. Possibilities of using non-wood semi-finished products from rapeseed soybean in composition with semi-finished products from wrappers to obtain packaging types of paper are shown.

Keywords: cob wrappers; delignification; fibrous semi-finished products; fibrillation; wrapping paper.

Fig.: 7. Table: 2. References: 20.

Черьопкіна Романія Іванівна - кандидат технічних наук, доцент, доцент кафедри екології та технології рослинних полімерів, Національний технічний університет України «Київський політехнічний університет імені Ігоря Сікорського» (просп. Перемоги,36, м. Київ, 03056, Україна).

Cheropkina Romaniia - PhD in Technical Sciences, Associate Professor of the Department of Ecology and Technology of Plant Polymers National Technical University of Ukraine «Igor Sikorsky Kyiv Polytechnic Institute» (36 Victory Av., 03056 Kyiv, Ukraine).

E-mail: chromi5@ukr.net

ORCID: http://orcid.org/ 0000-0001-9022-1576

Researcher iD: L-2005-2017

SCOPUS Author ID: 57222132228

Денисенко Анна Миколаївна - аспірант кафедри екології та технології рослинних полімерів Національного технічного університету України «Київський політехнічний інститут імені Ігоря Сікорського» (просп. Перемоги,36, м. Київ, 03056, Україна).

Denysenko Anna - PhD student of the Department of Ecology and Technology of Plant Polymers National Technical University of Ukraine «Igor Sikorsky Kyiv Polytechnic Institute» (36 Victory Av., 03056 Kyiv, Ukraine).

E-mail: anna.denysenko.7796@gmail.com

ORCID: http://orcid.org/0000-0001-8282-5433

Дейкун Ірина Михайлівна- кандидат технічних наук, доцент, доцент кафедри екології та технології рослинних полімерів, Національний технічний університет України «Київський політехнічний університет імені Ігоря Сікорського» (просп. Перемоги,36, м. Київ, 03056, Україна).

Deykun Irina - PhD in Technical Sciences, Associate Professor of the Department of Ecology and Technology of Plant Polymers National Technical University of Ukraine «Igor Sikorsky Kyiv Polytechnic Institute» (36 Victory Av., 03056 Kyiv, Ukraine).

E-mail: ir.d2615@gmail.com

ORCID: http://orcid.org/0000-0002-9562-0928

Researcher iD: AAJ-8659-2020

SCOPUS Author ID: 55062459700

Трембус Ірина Віталіївна- кандидат технічних наук, доцент, доцент кафедри екології та технології рослинних полімерів, Національний технічний університет України «Київський політехнічний університет імені Ігоря Сікорського» (просп. Перемоги,36, м. Київ, 03056, Україна).

Trembus Irina - PhD in Technical Sciences, Associate Professor of the Department of Ecology and Technology of Plant Polymers National Technical University of Ukraine «Igor Sikorsky Kyiv Polytechnic Institute» (36 Victory Av., 03056 Kyiv, Ukraine).

E-mail: tivkpi@gmail.com

ORCID: http://orcid.org/0000-0001-6985-4424

SCOPUS Author ID: 55227349800

Черьопкіна Р., Денисенко А., Дейкун І., Трембус І. Пакувальний папір із напівфабрикатів обгорток качанів кукурудзи. Технічні науки та технології. 2021. № 2(24). С. 159-170. 